CHINA'S UNCERTAIN FUTURE 



\section{JEAN-LUC DOMENACH}

TRANSLATED BY GEORGE HOLOCH

\section{China's}

\section{UNCERTAIN FUTURE}


Columbia University Press

Publishers Since 2893

New York Chichester, West Sussex

cup.columbia.edu

Columbia University Press wishes to express its appreciation for assistance given by the government of France through the Ministère de la Culture in the preparation of this translation.

Ouvrange publié avec le concours du ministère français chargé de la culture — Centre national du livre.

Originally published in French as La Chine m’inquiète, copyright (C) 2008 Perrin Translation copyright (C) 2012 Columbia University Press

All rights reserved

Library of Congress Cataloging-in-Publication Data

Domenach, Jean-Luc.

[Chine m'inquiète. English]

The emergence of modern China / Jean-Luc Domenach; translated by George Holoch. p. $\mathrm{cm}$.

Originally published in French under title : La Chine m'inquiète. Paris : Perrin, c2oo8. Includes bibliographical references and index.

ISBN 978-0-23 I-I 5224-2 (cloth : alk. paper) — ISBN 978-0-23I-52645-6 (e-book)

I. China-Politics and government-2002- 2. China-Social conditions-2000-

3. China-Economic conditions-2000- I. Title.

DS779.4.D6613 2012

$951.06-\mathrm{dc} 23$

Columbia University Press books are printed on permanent and durable acid-free paper. This book is printed on paper with recycled content.

Printed in the United States of America

c 1098765432 I

References to Internet Web sites (URLs) were accurate at the time of writing.

Neither the author nor Columbia University Press is responsible for URLs that may have expired or changed since the manuscript was prepared. 